Gut, 1978, 19, 521-525

\title{
Recognition of alcoholic liver disease in a district general hospital
}

\author{
A. J. LEVI AND D. M. CHALMERS
}

From the Division of Clinical Investigation, Northwick Park Hospital and Clinical Research Centre, Harrow, Middlesex

SUMMARY Two-hundred-and-two patients with alcoholic liver disease whose investigations included a liver biopsy were seen in a district general hospital over a seven year period. Thirty-five per cent presented with general gastrointestinal symptoms rather than with overt liver disease or previously recognised excess consumption of alcohol. Recognition of the alcohol problem was assisted by the finding of a raised mean corpuscular volume (MCV) and/or gammaglutamyl transpeptidase (GGTP). The use of these methods of detection is discussed in relation to the rapid rise in alcohol consumption in the United Kingdom, and the high mortality of cirrhosis reported from special centres. Twenty-two per cent of the patients were found to have an established cirrhosis, and there was some evidence that the women were more susceptible to some of the toxic effects of alcohol. Early detection can be enhanced by a high level of suspicion, wider recognition of the significance of a high MCV, and the greater use of GGTP estimations.

Recent studies have emphasised the increased importance of alcohol in the aetiology of liver disease seen in special referral units (Morgan and Sherlock, 1977; Krasner et al., 1977). As the mortality of established cirrhosis is high and alcohol consumption is increasing rapidly (Spring and Buss, 1977) the early recognition and treatment of alcoholic liver disease becomes particularly important in the United Kingdom at this time.

Many patients present to a district general hospital with digestive symptoms not previously recognised as being related to alcohol. In this paper the detection and recognition of alcoholic liver disease in 202 patients seen in a new district general hospital over seven years is described, together with their haematological, biochemical, and histological abnormalities.

\section{Methods}

\section{PATIENTS}

Northwick Park Hospital is a district general hospital serving a population of approximately 200000 in, and around, the London borough of Harrow. We have included in the study all patients with alcoholic liver disease for whom liver histology was available, and who presented between 1 January 1971 and 31 December 1977. All patients had clinical or biochemical evidence of liver disease together with a known or strongly suspected high intake of alcohol, and subsequent investigations showed no other cause of the abnormalities.

All patients were thought to have drunk more than $80 \mathrm{~g}$ of alcohol daily for at least one year, and, where sufficiently reliable information was available, they were divided into those drinking more, or less, than $160 \mathrm{~g} /$ day.

Liver function tests were performed by standard laboratory methods, and serum gammaglutamyl transpeptidase (GGTP) was measured by the method of Rosalki et al. (1970) in 146 patients. Mean corpuscular volume (MCV) was measured by a Coulter Counter Model S set so that the haematocrit excluded trapped plasma (England et al., 1972). Comparative values of MCV were obtained from 2296 people taking part in a prospective study of cardiovascular disease in a working population, and from 80 patients with non-alcoholic liver disease.

The appearances on liver histology were classified according to the following six categories: (1) normal (including four patients with minor non-specific infiltrates of mononuclear cells); (2) fatty change; (3) hepatofibrosis with or without fatty change; (4) alcoholic hepatitis characterised by extensive polymorphonuclear leucocyte infiltration, liver cell necrosis, and sometimes the presence of alcoholic hyaline; (5) cirrhosis; (6) cirrhosis and alcoholic hepatitis. One patient with cholestasis 
secondary to chronic alcoholic pancreatitis was excluded together with another with coexisting acute viral hepatitis.

Data were analysed using $2 \times 2 \chi^{2}$ or $t$ tests, and, as the values for aspartate transaminase (AST) and GGTP showed a log normal distribution, logarithmic conversion was carried out before statistical calculations.

\section{Results}

One-hundred-and-forty-four men and 58 women were included giving a sex ratio of $2 \cdot 5: 1$. There was no significant difference between the ages at presentation of the men $(52.8$ years standard deviation 11.2$)$ and the women $(54.0 \pm 11.6$ years $)$.

\section{ALCOHOL CONSUMPTION}

All patients had been drinking more than $80 \mathrm{~g} /$ day of alcohol which is equivalent to approximately $4 \frac{1}{2}$ pints of beer, two-thirds of a bottle of sherry, or onethird of a bottle of spirits. Over $90 \%$ of the patients had been actively drinking up until at least two weeks before admission and most were steady rather than 'spree' drinkers. Of the 168 patients whose consumption was thought to be reliably assessed, 56 of 127 men consumed more than $160 \mathrm{~g} /$ day compared with only 11 out of 41 women $\left(\chi^{2}=3 \cdot 85\right.$, $P<0.05$ ). The mean duration of heavy alcohol consumption was significantly longer for the men $(16.5 \pm 9.1$ years) than for the women $(8.9 \pm 5.6$ years, $\mathrm{P}<0.001)$. There was also a sex difference in the types of alcoholic beverage consumed. Just over $90 \%$ of the women predominantly drank sherry, wine, or spirits rather than beer or cider, while only $60 \%$ of the men came into this category.

\section{PRESENTATION}

This is shown in Table 1 . Only $29 \%$ of the patients presented because of known excessive drinking, and $35 \%$ had gastrointestinal symptoms not previously recognised as being alcohol related. Proportionately more women than men presented with gastrointestinal complaints such as dyspepsia, nausea, vomiting or diarrhoea but this difference just failed to reach statistical significance $\left(\chi^{2}=3.34\right.$ $0.1>P>0.05$ ).

MEAN CORPUSCULAR VOLUME

The MCV at presentation is shown in Table 2 together with the results from a large working population and a group of hospital patients with non-alcoholic liver disease. There was a highly significant increase in MCV of both sexes in the alcoholic groups. Also the mean MCV in the women $(102.9 \mathrm{fl})$ was significantly higher than in the men
Table 1 Presentation of 202 patients with alcoholic liver disease

\begin{tabular}{|c|c|c|c|c|c|c|}
\hline & \multicolumn{2}{|c|}{ Men } & \multicolumn{2}{|c|}{ Women } & \multicolumn{2}{|c|}{ Total } \\
\hline & No. & $\%$ & No. & $\%$ & No. & $\%$ \\
\hline $\begin{array}{l}\text { Gastrointestinal } \\
\text { Alcoholism } \\
\text { Overt liver disease } \\
\text { Other }\end{array}$ & $\begin{array}{l}45 \\
44 \\
16 \\
39\end{array}$ & $\begin{array}{l}31 \cdot 3 \\
30 \cdot 6 \\
11 \cdot 1 \\
27 \cdot 0\end{array}$ & $\begin{array}{r}26 \\
14 \\
6 \\
12\end{array}$ & $\begin{array}{l}44 \cdot 8 \\
24 \cdot 1 \\
10 \cdot 3 \\
20 \cdot 7\end{array}$ & $\begin{array}{l}71 \\
58 \\
22 \\
51\end{array}$ & $\begin{array}{l}35 \cdot 1 \\
28 \cdot 7 \\
10 \cdot 9 \\
25 \cdot 3\end{array}$ \\
\hline Number & 144 & & 58 & & 202 & \\
\hline
\end{tabular}

Table 2 Mean corpuscular volume (MCV)

\begin{tabular}{|c|c|c|c|c|}
\hline & \multicolumn{2}{|l|}{ Men } & \multicolumn{2}{|c|}{ Women } \\
\hline & No. & $\begin{array}{l}\text { Mean } M C V \\
\pm S D\end{array}$ & No. & $\begin{array}{l}\text { Mean } M C V \\
\pm S D\end{array}$ \\
\hline $\begin{array}{l}\text { Working population } \\
\text { Non-alcoholic liver } \\
\text { disease }\end{array}$ & $\begin{array}{r}1588 \\
38\end{array}$ & $\begin{array}{l}86 \cdot 2 \pm 3 \cdot 91 \\
86 \cdot 0 \pm 4 \cdot 30\end{array}$ & $\begin{array}{r}708 \\
42\end{array}$ & $\begin{array}{l}86 \cdot 1 \pm 4 \cdot 39 \\
87 \cdot 2 \pm 3 \cdot 72\end{array}$ \\
\hline Alcoholic liver disease & 140 & $* 97.4 \pm 7.87$ & 58 & ${ }^{*} 102.9 \pm 8.32$ \\
\hline
\end{tabular}

*For both men and women the MCV was significantly higher than in normal subjects $(\mathrm{P} \ll 0.001)$ and $\mathrm{MCV}$ in women with alcoholic liver disease was higher than in the men $(P<0.001)$.

$(97.4 \mathrm{fl}, \mathrm{P}<0.001)$. The rise in MCV seems to be largely due to recent alcohol consumption, as 10 of the patients who had not been drinking for at least one month before admission had a much lower MCV of $88.0 \pm 4 \cdot 5 \mathrm{fl}$.

LIVER FUNCTION TESTS

The results for AST and GGTP at presentation are shown in Table 3. GGTP values were more frequently raised than the AST, and the percentage increase above the reference range was much greater for GGTP. There was considerable overlap in the enzyme values found in the various histological groups, and although mean GGTP levels were highest in patients with alcoholic hepatitis this was not statistically significant after logarithmic transformation. The group with normal histology had a significantly lower mean AST and GGTP $(P<0.001)$ than other categories. In women the mean GGTP was higher than in the men $(204.4 \mathrm{cf} .138 .4 \mathrm{IU} / \mathrm{l}$, $P<0.05$ ). This sex difference was not observed with AST. No significant correlation was found between MCV and GGTP for either men $(r=0.062)$ or women $(r=0.0035)$.

\section{LIVER HISTOLOGY}

This is shown in Table 4. Twenty-two per cent of the total had an established cirrhosis with or without associated alcoholic hepatitis. Although a larger percentage of the women were cirrhotic $(25.8 \% \mathrm{cf}$. $20.1 \%$ ) this failed to reach statistical significance. When the pattern of alcoholic liver damage was 
Table 3 Comparison of AST and GGTP values at presentation

\begin{tabular}{|c|c|c|}
\hline & $A S T$ & $G G T P$ \\
\hline & $\begin{array}{l}\text { Reference range } 0-35 \\
I U / 1\end{array}$ & $\begin{array}{l}\text { Reference range } 0-60 \\
\text { IU } / 1\end{array}$ \\
\hline \multirow{3}{*}{$\begin{array}{l}\text { Number of } \\
\text { patients } \\
\% \text { of results } \\
\text { abnormal } \\
\% \text { increase in } \\
\text { mean AST and } \\
\text { GGTP above } \\
\text { upper limit } \\
\text { of normal }\end{array}$} & 202 & 146 \\
\hline & $68 \cdot 8$ & $87 \cdot 7$ \\
\hline & 90 & $303 \cdot 3$ \\
\hline
\end{tabular}

Table 4 Liver histology in relation to sex and age

\begin{tabular}{|c|c|c|c|c|c|}
\hline \multirow[t]{2}{*}{$\begin{array}{l}\text { Histological } \\
\text { category }\end{array}$} & \multirow[t]{2}{*}{$\begin{array}{l}\text { Men } \\
\%\end{array}$} & \multirow[t]{2}{*}{$\begin{array}{l}\text { Women } \\
\%\end{array}$} & \multirow[t]{2}{*}{$\begin{array}{l}\text { Total } \\
\%\end{array}$} & \multicolumn{2}{|c|}{$\begin{array}{l}\text { Age at presentation } \\
(\%)\end{array}$} \\
\hline & & & & $\leqslant 55$ & $>55$ \\
\hline Normal & $17 \cdot 4$ & 10.3 & $15 \cdot 3$ & $16 \cdot 7$ & 13.4 \\
\hline Fatty change & 38.9 & $48 \cdot 3$ & $41 \cdot 6$ & $49 \cdot 2$ & $30 \cdot 5$ \\
\hline $\begin{array}{l}\text { Hepatofibrosis } \\
\pm \text { fat }\end{array}$ & $16 \cdot 0$ & $10 \cdot 4$ & $14 \cdot 4$ & $10 \cdot 8$ & $19 \cdot 5$ \\
\hline Alcoholic hepatitis & $7 \cdot 6$ & $5 \cdot 2$ & 6.9 & 7.5 & $6 \cdot 1$ \\
\hline Cirrhosis & $17 \cdot 3$ & $24 \cdot 1$ & $19 \cdot 3$ & $14 \cdot 2$ & $26 \cdot 8$ \\
\hline $\begin{array}{l}\text { Cirrhosis }+ \\
\text { alcoholic } \\
\text { hepatitis }\end{array}$ & $2 \cdot 8$ & 1.7 & $2 \cdot 5$ & $1 \cdot 6$ & $3 \cdot 7$ \\
\hline Number & 144 & 58 & 202 & 120 & 82 \\
\hline
\end{tabular}

analysed according to age, fatty change was found significantly more frequently in the younger patients $(\mathrm{P}<0.01)$, and cirrhosis was more common in the over 55 year old group $(P<0.02)$. In the male patients those with normal histology or fatty change had shorter mean durations of heavy drinking (16.2 and 13 years respectively) compared with a mean duration of 22.1 years in the cirrhotic group (normal, $\mathrm{P}<0.05$; fatty change, $\mathrm{P}<0.001$ ). Alcoholic hepatitis was found in only $9.4 \%$ of the patients and was not found more frequently in the women.

\section{Discussion}

Over the period 1965-75 the amount of wine consumed in the United Kingdom more than doubled, and total alcohol consumption increased by approximately $30 \%$ (National Council on Alcoholism, 1976). Recent figures show that the average daily intake for each adult is approaching $20 \mathrm{~g} /$ day. Epidemiological studies from France (Pequignot et al., 1974; Pequignot and Tuyns, 1975) suggest that the prevalence of cirrhosis is increased in men who regularly drink more than $60 \mathrm{~g} /$ day, and in women after $20 \mathrm{~g} /$ day. The mortality of established cirrhosis is high, especially if drinking continues (Brunt $e t$ al.,
1974; Krasner et al., 1977). Early detection of alcoholic liver disease therefore appears to be crucial to prevent an epidemic of death from alcoholic cirrhosis.

The commonest mode of presentation of patients was with ill-defined gastrointestinal symptoms, and less than one-third were seen because of known excessive alcohol consumption. As only a small percentage of patients with alcoholic liver disease presenting to a district general hospital have overt liver disease (jaundice, ascites, hepatic encephalopathy, or variceal bleeding) we have studied the use of red cell indices and liver enzymes in the detection of patients without overt liver disease.

We have previously shown (Wu et al., 1974) that $85 \%$ of a group of patients regularly drinking more than $80 \mathrm{~g} /$ day of alcohol had a rise in mean corpuscular volume as measured by a Coulter Counter. This macrocytosis of alcoholism is often unrelated to folate deficiency and appears to be due to a direct toxic effect on the developing erythroblast (Wu et al., 1975). The present study confirms that MCV is significantly raised in patients who are ultimately found to be drinking more than $80 \mathrm{~g} / \mathrm{day}$, and the macrocytosis was more marked than in patients with non-alcoholic liver disease. Other causes of macrocytosis, such as $\mathbf{B}_{12}$ deficiency or thyroid disease, were excluded by appropriate tests. The rise in MCV appears to be primarily related to a high alcohol intake as patients who were not actively drinking showed a much lower MCV. We have also observed that MCV falls towards normal levels after alcohol withdrawal even in cirrhotic patients, and can be used as an indicator of continued abstinence or of heavy drinking. The explanation of the significantly higher MCV in the female alcoholics is not clear from this analysis, but it suggests that women may be more susceptible to the macrocytosis of alcoholism.

Our findings confirm previous work (Zein and Discombe, 1970; Rosalki and Rau, 1972; Dragosics et al., 1976) which has shown that GGTP is a more sensitive indicator of alcohol induced liver injury than AST; in this study it was found to be abnormal in $88 \%$ of patients. Although there is some relationship between GGTP and the extent of liver cell necrosis (Wu et al., 1976), and the values were higher in these series for patients with alcoholic hepatitis, there was considerable overlap between the various histological groups. GGTP seems to be most useful for detection of alcohol related liver damage rather than estimation of liver cell necrosis, although in an individual the degree of damage and the presence of cirrhosis cannot be predicted from the level.

The pattern of histological liver damage showed marked differences from that recently reported by 
special referral centres. Both Morgan and Sherlock (1977) and Krasner et al. (1977) reported that $57 \%$ and $58 \%$ respectively of their patients had cirrhosis with or without alcoholic hepatitis, compared with only $22 \%$ in this series. We found alcoholic hepatitis in just under $10 \%$ and only one patient was found to have a hepatoma. Unlike Glover et al. (1977) we found no patients with 'acute alcoholic cholestasis' in the absence of alcoholic hepatits, cirrhosis, or extrahepatic obstruction. Our findings are similar to the results of Eghöje and Juhl (1973) who found cirrhosis in $18 \%$ of a consecutive series of 347 chronic alcoholics. Like them, we have also shown a clear relationship between the prevalence of cirrhosis and the length of drinking history.

This series also lends some support to the suggestion that women are more susceptible to alcoholic liver disease (Spain, 1945; Wilkinson et al., 1969; Pequignot et al., 1974; Ashley et al., 1977; Krasner et al., 1977; Morgan and Sherlock, 1977). Although the greater prevalence of cirrhosis among female patients did not reach statistical significance, and alcoholic hepatitis was not more frequent, it is interesting that GGTP levels were higher in the women. The women also tended to drink smaller amounts of alcohol and they had a much shorter mean duration of excessive drinking. It has been argued that women might tend to underestimate their consumption to a greater extent than men (Hamlyn, 1977), but some corroboration of alcohol intake was obtained from relatives of the majority of women in the series. Women therefore appear to develop alcoholic liver disease of equivalent or greater severity to men in spite of having consumed smaller quantities of alcohol.

As the pattern of alcohol consumption in a drinking population shows a logarithmic normal distribution (Rankin et al., 1975) the recent increase in per capita consumption in the United Kingdom (Spring and Buss, 1977) is likely to result in a disproportionate rise in the numbers at risk of developing alcoholic liver disease. Our experience suggests that identification of these patients will be aided by a high degree of suspicion (especially in women with undiagnosed gastrointestinal symptoms), investigation of any unexplained macrocytosis, and the greater use of GGTP estimations in the assessment of liver function.

We thank DrT. W. Meade and the epidemiology and medical care unit for permission to quote from their data on MCV of a large working population. We also thank the departments of clinical chemistry, haematology, and histopathology, and the division of medical computing, for measurements and assistance. D.M.C. is a Medical Research Council Training Fellow.

\section{References}

Ashley, M. J., Olin, J. S., Harding le Riche, W., Kornaczewski, A., Schmidt, W., and Rankin, J. G. (1977). Morbidity in alcoholics. Archives of Internal Medicine, 137, 883-887.

Brunt, P. W., Kew, M. C., Scheuer, P. J., and Sherlock, S. (1974). Studies in alcoholic liver disease in Britain. Gut, $15,52-58$.

Dragosics, B., Ferenci, P., Pesendorfer, F., and Wewalka, F. G. (1976). Gamma-glutamyltranspeptidase (GGTP): its relationship to other enzymes for diagnosis of liver disease. Progress in Liver Diseases, 5, 436-449. Edited by $\mathrm{H}$. Popper and F. Schaffner. Grune and Stratton: New York.

Eghöje, K. N., and Juhl, E. (1973). Factors determining liver damage in chronic alcoholics. Scandinavian Journal of Gastroenterology, 8, 505-512.

England, J. M., Walford, D. M., and Waters, D. A. W. (1972). Re-assessment of the reliability of the haematocrit. British Journal of Haematology, 23, 247-256.

Glover, S. C., McPhie, J. L., and Brunt, P. W. (1977). Cholestasis in acute alcoholic liver disease. Lancet, 2, 1305-1306.

Hamlyn, A. N. (1977). Alcoholic liver disease in women. British Medical Journal, 1, 1085-1086.

Krasner, N., Davis, M., Portmann, B., and Williams, R. (1977). Changing patterns of alcoholic liver disease in Great Britain: relation to sex and signs of autoimmunity. British Medical Journal, 1, 1497-1500.

Morgan, M. Y., and Sherlock, S. (1977). Sex-related differences among 100 patients with alcoholic liver disease. British Medical Journal, 1, 939-941.

National Council on Alcoholism (1976). 13th Annual Report, 1975-76, 45.

Pequignot, G., Chabert, C., Eydoux, H., and Courcoul, M. A. (1974). Increased risk of liver cirrhosis with intake of alcohol. Review of Alcoholism, 20, 191-202.

Pequignot, G., and Tuyns, A. (1975). 'Declared' amount of alcohol consumption and risks of diseases. In AngloFrench Symposium on Alcoholism, Editions INSERM: Paris.

Rankin, J. G., Schmidt, W., Popham, R. E., and de Lint, J. (1975). Epidemiology of alcoholic liver disease-insights and problems. In Alcoholic Liver Pathology, pp. 31-41. Edited by J. M. Khanna, Y. Israel, and H. Kalant. Alcoholism and Drug Addiction Research Foundation of Ontario: Toronto.

Rosalki, S. B., and Rau, D. (1972). Serum $\gamma$-glutamyl transpeptidase activity in alcoholism. Clinica Chimica Acta, 39, 41-47.

Rosalki, S. B., Rau, D., Lehmann, D., and Prentice, M. (1970). Determination of serum gamma-glutamyl transpeptidase activity and its clinical applications. Annals of Clinical Biochemistry, 7, 143-147.

Spain, D. M. (1945). Portal cirrhosis of the liver: a review of 250 necropsies with references to sex differences. American Journal of Clinical Pathology, 15, 215-218.

Spring, J. A., and Buss, D. H. (1977). Three centuries of alcohol in the British diet. Nature, 270, 567-572.

Wilkinson, P., Santamaria, J. N., and Rankin, J. G. (1969). Epidemiology of alcoholic cirrhosis. Australasian Annals of Medicine, 18, 222-226.

Wu, A., Chanarin, I., and Levi, A. J. (1974). Macrocytosis of chronic alcoholism. Lancet, 1, 829-831.

Wu, A., Chanarin, I., Slavin, G., and Levi, A. J. (1975). Folate deficiency in the alcoholic-its relationship to clinical and haematological abnormalities, liver disease 
and folate stores. British Journal of Haematology, 29, 469-478.

Wu, A., Slavin, G., and Levi, A. J. (1976). Elevated serum gamma-glutamyl transferase (transpeptidase) and histo- logical liver damage in alcoholism. American Journal of Gastroenterology, 65, 318-323.

Zein, M., and Discombe, G. (1970). Serum gamma-glutamyl transpeptidase as a diagnostic aid. Lancet, 2, 748-750.

\section{The May 1978 Issue}

\section{THE MAY 1978 ISSUE CONTAINS THE FOLLOWING PAPERS}

Mitochondrial enzyme activities in liver biopsies from patients with alcoholic liver disease W. J. JENKINS AND T. J. PETERS

Familial and nonfamilial benign recurrent cholestasis distinguished by plasma disappearance of indocyanine green but not cholylglycine G. P. VAN BERGEHENEGOUWEN, D. R. FERGUSON, A. F. HOFMANN, AND A. G. F. DE PAGTER

Pancreatic and salivary amylase/creatinine clearance ratios in normal subjects and in patients with chronic pancreatitis J. E. HEGARTY, MARY D. O'DONNELL, K. F. MCGEENEY, AND O. FITZGERALD

Comparison of the biological potency of a new synthetic preparation of secretin with that of natural porcine secretin in the dog $\mathrm{K}$. GYR, L. KAYASSEH, W. W. RITTMANN, J. GIRARD, AND G. A. STALDER

Pancreatic enzymes in human duodenal juice-a comparison of responses in secretin pancreozymin and Lundh Borgström tests JOAN M. BRAGANZA, K. HERMAN, PAULINE HINE, G. KAY, AND G. I. SANDLE

Acute pancreatitis and serological evidence of infection with Mycoplasma pneumoniae R. FREEMAN AND M. J. MCMAHON

Comparison of radio-opaque pellets and chromium sesquioxide as inert markers in studies requiring accurate faecal collections W. J. BRANCH AND J. H. CUMMINGS

Effect of codeine phosphate, Lomotil, and Isogel on ileostomy function C. R. NEWTON

Age-related changes in the colonic blood supply: their relevance to ischaemic colitis J. C. BINNS AND P. ISAACSON
Is there a myoelectrical abnormality in the irritable colon syndrome? I. TAYLOR, C. DARBY, P. HAMMOND, AND P. BASU

Transmucosal potential difference; diagnostic value in gastro-oesophageal reflux B. KHAMIS, C. KENNEDY, J. FINUCANE, AND J. STEPHEN DOYLE

Motilin release in the pig I. M. MODLIN, P. MITZNEGG, AND S. R. BLOOM

Electron immunohistochemical evidence for the human intestinal I cell as the source of CCK ALISON M. J. BUCHAN, JULIA M. POLAK, E. SOLCIA, C. CAPELLA, D. HUDSON, AND A. G. E. PEARSE

Immunohistochemical localisation of urogastrone to human duodenal and submandibular glands Ph. U. HEITZ, MARLIS KASPER, SUSAN VAN NOORDEN, JULIA M. POLAK, H. GREGORY, AND A. G. E. PEARSE

Effect of cimetidine on ion fluxes and potential difference across the human stomach $K$. J. IVEY AND P. A. MACKERCHER

Effect of ulcer healing on the prognosis of chronic gastric ulcer D. W. PIPER, JANE SHINNERS, MARGARET GREIG, JOAN THOMAS, AND SHEILA L. WALLER

The two histological types of gastric carcinoma in Northern Nigeria o. A. MABOGUNJE, o. G. SUBBUSWAMY, AND J. H. LAWRIE

Notes and activities

Books

The British Society of Gastroenterology

Copies are still available and may be obtained from the PUBLISHING MANAGER, BRITISH MEDICAL ASSOCIATION, TAVISTOCK SQUARE, LONDON WC1H 9JR, price $£ 2 \cdot 75$, including postage 